Nippon Suisan Gakkaishi $\quad$ 53(3), 473-478 (1987)

\title{
Sexual Reproduction and Cyst Formation in the Freshwater Dinoflagellate Peridinium penardii
}

\author{
Yoshihiko Sako, ${ }^{* 1}$ Yuzaburo Ishida, ${ }^{* 1}$ Toshitaka Nishijima, ${ }^{* 2}$ \\ and Yoshihiko Hata*2 \\ (Accepted July 9, 1986)
}

\begin{abstract}
The prospect that the cyst might be a seed population in the bloom of Peridinium penardit in spring in Nagase Reservoir, Kochi Prefecture, the conditions regulating encystment of this species were examined by use of clonal population in a synthetic medium (MW2). Sexual reproduction was induced by incubating late logarithmic phase cells in nitrogen and phosphorus deficient medium. Two gametes, which were small and naked in shape, were produced from thecate cells. The gamete was isogamous and homothallic. The planozygote did not retain red bodies and remained motile for 7-14 days. About 14 days after plasmogamy the zygote became nonmotile, the protoplast expanded and the wall thickened. The theca of planozygote split at the girdle region and the hypnozygote (cyst) was produced. The maximum frequency of encystment was $40 \%$ under $10,000 \mathrm{~lx}$ illumination at $15^{\circ} \mathrm{C}$ in $\mathrm{N}$-free or $\mathrm{N}$ - and P-free medium. The frequencies of encystment in P-free medium and fresh medium containing $\mathrm{N}$ and $\mathbf{P}$ were about 5 and $0 \%$, respectively. Optimum condition for encystment was $15^{\circ} \mathrm{C}$ and 5,000 to $10,000 \mathrm{~lx}$.
\end{abstract}

Recently large-scale freshwater red tides of dinofiagellates belonging to the genus Peridinium have often occurred in many reservoirs in Western Japan. ${ }^{1)}$ In Nagase Reservoir in Kochi Prefecture we found that every year large blooms of Peridinium penardii occurred from winter to spring, as well as $\boldsymbol{P}$. cunning tonii in every summer. ${ }^{2)}$ The succession of dominant species from $P$. penardii to $P$. cunningtonii occurs at above $17^{\circ} \mathrm{C}$, in late spring to early summer. $P$. penardii and $P$. cunningtonii, which appear in the reservoir only in limited seasons during a year, probably spend most of the other seasons as dormant and resting cysts. ${ }^{3}$

In the previous papers, ${ }^{4,5}$ ) we made clear the life cycle and the environmental conditions which induce encystement and excystment in $\boldsymbol{P}$. cunningtonii. Sexual reproduction in $P$. cunningtonii was induced by incubating clonal vegetative cells in nitrogen- and/or phosphorus-deficient medium (a) at $15-20^{\circ} \mathrm{C}$ under illumination $(10,000$ $\mathrm{lx}, 14 \mathrm{~L}: 10 \mathrm{D}$ ), the homothallic fusing gametes developed into hypnozygote (cyst) through planozygote, and the maximum frequency of encystment was $70 \%$. Sexual reproduction of Peridinium sp. B3, ${ }^{0)} P$. cinctum ${ }^{7)} P$. wille ${ }^{7}{ }^{8)}$ and
$P$. gatunense, ${ }^{\theta>}$ was similar to that of $P$. cunningtonii, ${ }^{4)}$ although these studies were not quantitative.

The first objective of this study is to prove an interesting life cycle of $\boldsymbol{P}$. penardii. The second objective of this study is to make clear the conditions regulating encystment of this species by use of clonal population and synthetic medium.

\section{Materials and Methods}

\section{Organism}

Peridinium penardii was isolated from Nagase Reservoir, Kochi Prefecture. Clonal and axenic culture was utilized in all experiments.

\section{Culture}

All cultures of $P$. penardii were grown in $100 \mathrm{ml}$ Erlenmeyer flasks. Cells were grown at $15^{\circ} \mathrm{C}$ on a $14: 10 \mathrm{~h}$ light-dark cycle under illumination of $10,000 \mathrm{~lx}$ provided by banks of $30 \mathrm{w}$ cool white fluorescent lamps. No bubbling or shaking of culture was employed.

$P$. penardii was grown in MW2 medium which is the modified medium of Watanabe's medium. ${ }^{102}$ The composition of MW2 medium was shown in

*1 Laboratory of Microbiology, Department of Fisheries, Faculty of Agriculture, Kyoto University, Kyoto

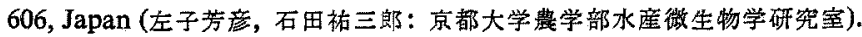

*2 Laboratory of Aquatic Environmental Science, Department of Cultural Fisheries, Faculty of Agriculture, Kochi University, Kochi 783, Japan (西岛敏隆, 烟 幸彦: 高知大学農学部栽培漁栄学科水族環境学研究 㱏). 
Table 1. Composition of MW2 medium for Peridinium penardii

\begin{tabular}{lc}
\hline \multicolumn{1}{c}{ Ingradient } & Concentration $\left(l^{-1}\right)$ \\
\hline Urea & $8.5 \mathrm{mg}$ \\
$\mathrm{Ca}\left(\mathrm{NO}_{3}\right)_{2} \cdot 4 \mathrm{H}_{2} \mathrm{O}$ & $100 \mathrm{mg}$ \\
$\mathrm{KNO}_{3}$ & $10 \mathrm{mg}$ \\
$\beta$-Glycerophosphoric acid & $20 \mathrm{mg}$ \\
$\quad$ disodium salt & $15 \mathrm{mg}$ \\
$\mathrm{MgSO}_{4} \cdot 7 \mathrm{H}_{2} \mathrm{O}$ & $0.5 \mathrm{ml}$ \\
P IV metal & $0.2 \mu \mathrm{g}$ \\
Vitamin $\mathrm{B}_{12}$ & $20 \mu \mathrm{g}$ \\
Thiamin hydrochloride & $0.2 \mu \mathrm{g}$ \\
Biotin & $100 \mathrm{mg}$ \\
Glycylglycine & $\vdots$
\end{tabular}

Table 1.

Cell numbers were determined with a hemocytometer after fixation with formalin.

\section{Encystment Experiment}

When cell density of the cultures reached $5 \times 10^{4}$ cells $\cdot \mathrm{m} l^{-1}$ for 3 weeks, the cell were transferred at a final concentration of $c a .400 \mathrm{cells} \cdot \mathrm{m} l^{-1}$ to fresh MW2 medium without nitrogen and/or phosphorus. Unless otherwise noted the standard conditions for sexual reproduction and encystment were: i) $\mathbf{N}$ - and P-free MW2 medium; ii) incubation temperature at $15^{\circ} \mathrm{C}$; and, iii) illumina- tion of $10,000 \mathrm{~lx}$ on $14: 10 \mathrm{~h}$ LD cycle. Conditions for nutrient, light and temperature during sexual reproduction were modified áccording to experimental design. At short intervals the number of hypnozygotes (cysts) was counted. A frequency of cyst formation (\%) was calculated using the following formula:

Frequency of cyst formation $(\%)^{4)}$

$$
=\frac{2 \times\left(\text { number of cysts } \cdot \mathrm{m} l^{-1}\right)}{\left(\text { number of vegetative cells } \cdot \mathrm{m} l^{-1}\right)} \times 100
$$

\section{Observation of Life Cycle}

The sexual life cycle was followed by isolating single pairs of fusing gametes on $0.2 \mathrm{ml}$ of media poured into each hole in Microtest Plates (Nunclon). These zygotes formed were checked daily by an inverted microscope (Nikon TMD). The more detail microscopic observations were made with a differential interference microscope (Nikon XF-NT) equipped with a camera (Nikon UFX-II).

\section{Results}

\section{Vegetative Growth}

A typical growth curve and growth condition of $P$. penardii was shown in Fig. 1. The maximum
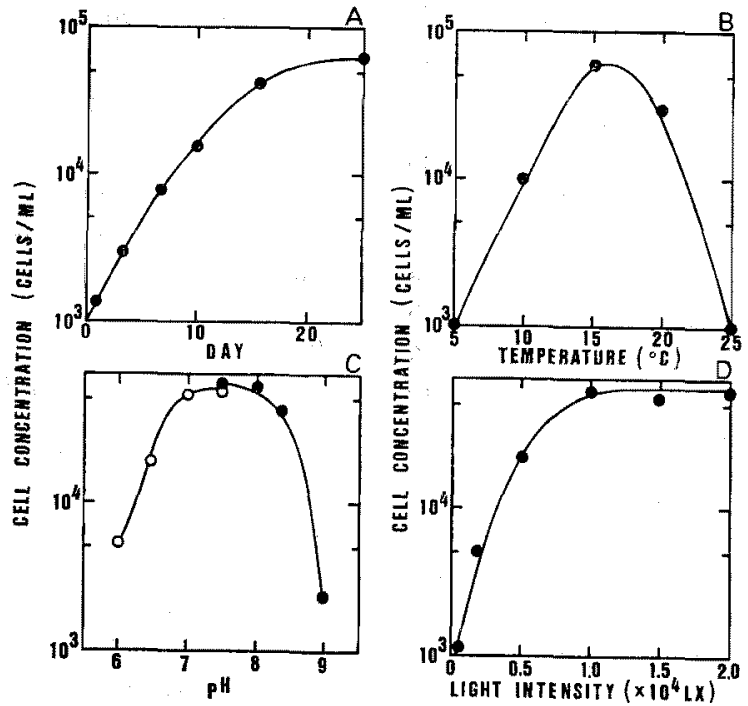

Fig. 1. Growth curve of $P$. penardii in MW2 medium.

A, Standard growth curve in a culture incubated at $15^{\circ} \mathrm{C}$ on a $14: 10 \mathrm{~h}$ LD cycle under illumination of $10,000 \mathrm{~lx}$. B, Temperature effect. $\mathrm{C}, \mathrm{pH}$ effect $(\mathrm{O}, \mathrm{MW} 2$ with PIPES (Piperazine- $N, N^{\prime}$-bis(2-ethanesulfonic acid)) in place of glycylglycine; 9 , MW2 medium). D, Light intensity effect. 


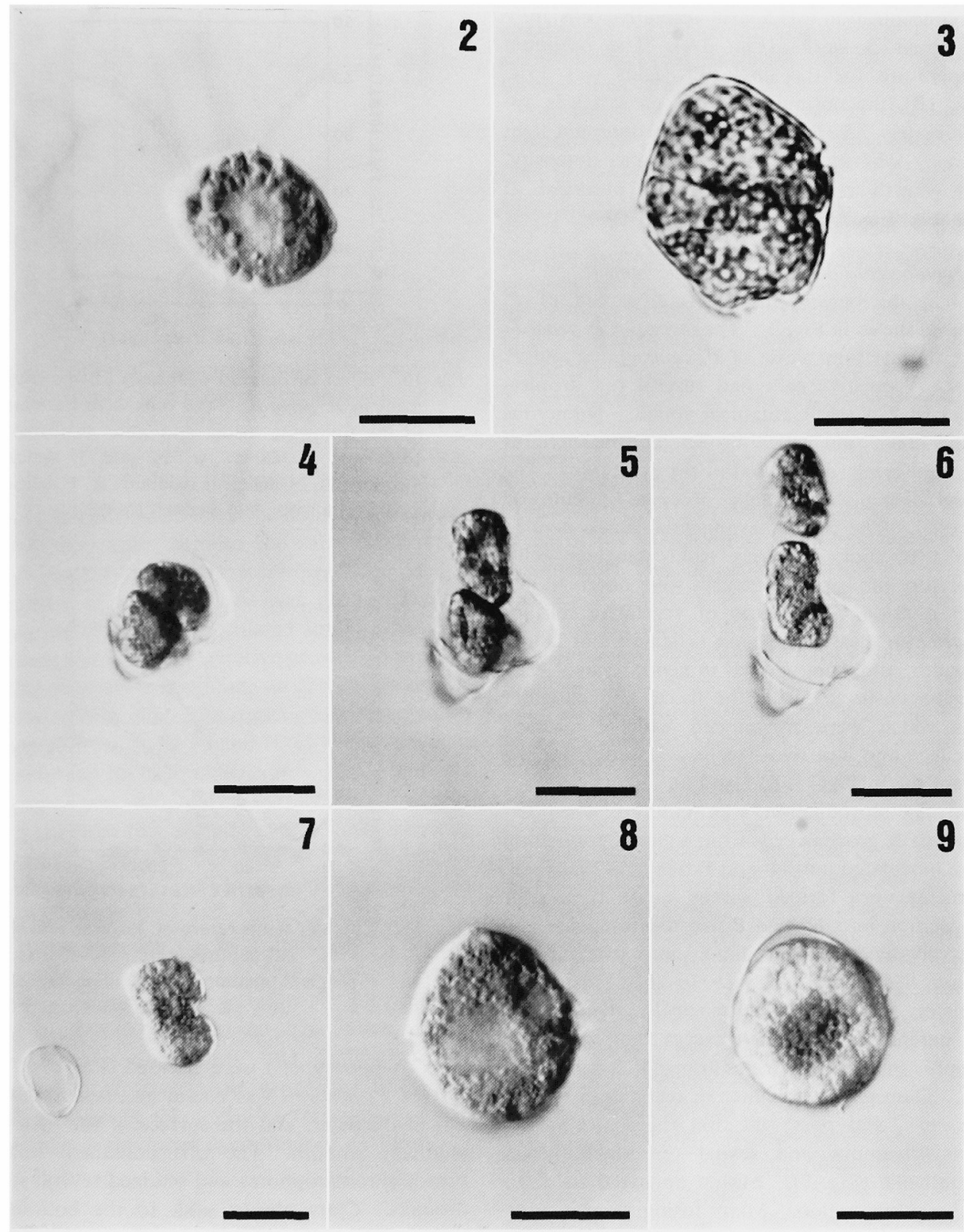

Figs. 2-9. Light micrographs of division and encystment in $P$. penardii. Scale bars $=20 \mu \mathrm{m}$.

Fig. 2. Vegetative cell.

Fig. 3. Two daughter vegetative division. Cleavage furrow is obliquely complete.

Fig. 4. Burst of theca.

Figs. 5, 6. Release of daughter cells.

Fig. 7. Fusion of gametes.

Fig. 8. Planozygote.

Fig. 9. Cyst. 
cell concentration was $5 \times 10^{4}$ vegetative cells $\cdot \mathrm{m} l^{-1}$ for about 3 weeks (Fig. 1A). The optimum temperature for the final cell yields was $15^{\circ} \mathrm{C}$ (Fig. 1B), the optimum $\mathrm{pH}$ for growth was approximately 7.5 (Fig. 1C), and the optimum light intensity was at $10,000 \mathrm{~lx}$ and higher intensity. The growth reductions were not observed at 20,000 lx (Fig. 1D).

\section{Morphological Observations of Encystment}

Light micrograph of a vegetative cell of $P$. penardii shows in Fig. 2. The thecae of $P$. penardii were thinner than those of $P$. cunningtonit and $P$. bipes. Vegetative cells had several red droplets and had 2-4 small antapical spines. Numerous yellow-green or yellow-brown chromatophores were uniformly distributed in the cytoplasm. The thecal debris were usually observed in cultured material. The cells in exponential phase divided into two, four or rarely eight daughter cells. Therefore the various size cells were observed just after division. Mean size of vegetative cells of $P$. penardii measured $30 \mu \mathrm{m}$ in length and $28 \mu \mathrm{m}$ in width, and were ovoidal in ventral view. Cell division occurred inside the theca, and daughter cells which were surrounded with a colorless mucilage and had two flagella released from the parent theca (Figs. 3, 4, 5 and 6).

Sexual reproduction was induced when exponentially growing cells from a clonal population were inoculated into $\mathrm{N}$ - and P-free MW2 medium. Gametes were formed within a few days after inoculation into $\mathrm{N}$ - and $\mathbf{P}$-free medium. Vegetative cell divided longitudinally into two gametes within the parental theca. In this species the gametes appeared morphologically identical to the parent vegetative cell except that they were usually smaller. Gametes ranged from 20-25 $\mu \mathrm{m}$. Gametes were lighter in color than vegetative cells, and possessed thin thecae. Gametes were isogamous and sexual reproduction was homothellic (Fig. 7). Fusion appeared to occur in the sulcus region. Many fusing gametes were observed during the dark phase of LD cycle. Sexual fusion was completed within about 1-2 h.

Within $24 \mathrm{~h}$ the planozygote readily developed its own thecae (Fig. 8), had two longitudinal flagella and remained motile for about 10 days after fusion, but didn't retain red body. During that time the planozygote slowly enlarged to 33 $37 \mu \mathrm{m}$ and became dark in color. Ten days after the planozygote lost motility, it settled on the bottom of culture vessel and then shed its thecae. After the thecae split at the girdle region, the

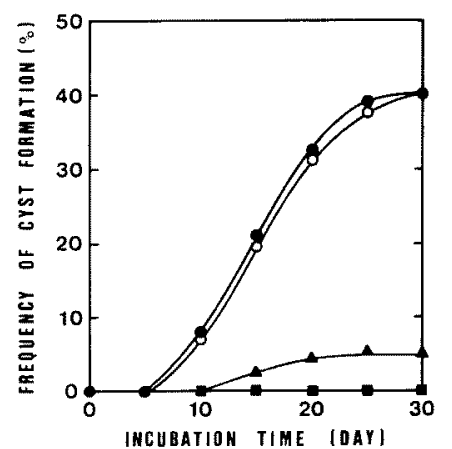

Fig. 10. Effect of nutrient deficiency on the encystment in $P$. penardi', The cells were transferred to the following media and were incubated at $15^{\circ} \mathrm{C}$ and $10,0001 \mathrm{x}$. $\bullet, N$ and $\mathrm{P}$ deficient medium; $O, \mathrm{~N}$ deficient medium; $\boldsymbol{\Delta}, \mathrm{P}$ deficient medium; $\mathbf{\square}$, complete medium (MW2).

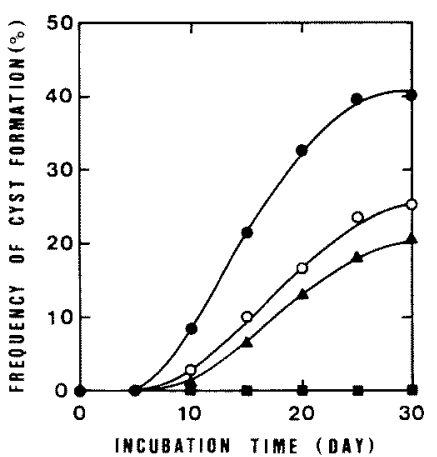

Fig. 11. Effect of temperature on the encystment of $P$. penardii. All cultures were incubated in $\mathrm{N}$ and P-deficient medium under illumination of $10,000 \mathrm{~lx} .0,20^{\circ} \mathrm{C} ; 15^{\circ} \mathrm{C} ; \mathbf{A}, 10^{\circ} \mathrm{C} ; \mathbf{E}, 5^{\circ} \mathrm{C}$.

cysts (hypnozygotes) were released (Fig. 9). The cyst of $P$. penardii was round and was about 28 $\mu \mathrm{m}$ in diameter, and the surface of the cyst was relatively smooth. The cyst contained yellowbrown chromatophores and retained several small droplets. Cysts always sank to the bottom of the test tube. By excreting mucilaginous material the cysts were easily aggregated or stuck the thecae of vegetative cells around each cyst.

\section{Effect of Environmental Conditions on Encystment}

The effect of nutrient ( $\mathrm{N}$ and/or P) deficiency on the encystment of $P$. penardii was investigated. Results obtained are shown in Fig. 10. Thirty days after inoculating of the vegetative cells into $\mathrm{N}$ - and $\mathrm{P}$-free medium cysts were produced at the frequency of $40 \%$ under $10,000 \mathrm{~lx}$ illumination at 


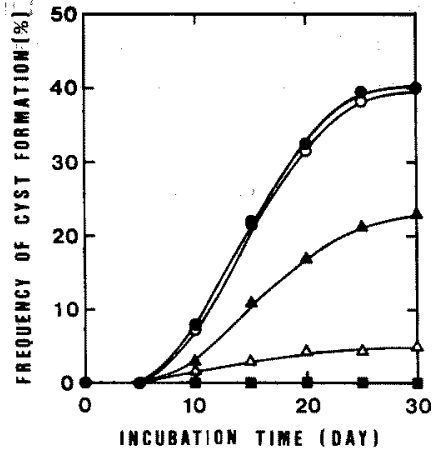

Fig. 12. Effect of light intensity on the encystment of $P$. penardii. All cultures were incubated in Nand P-deficient medium at $15^{\circ} \mathrm{C}$. $\quad 10,000 \mathrm{~lx}$; $0,5,000 \mathrm{~lx} ; \Delta, 2,000 \mathrm{~lx} ; \Delta, 1,000 \mathrm{~lx} ; \mathbf{\square}$, dark.

$15^{\circ} \mathrm{C}$. In the case of $\mathrm{N}$-free medium the frequency of cyst formation showed the same value also. In P-free medium cysts were produced at the frequency of $5 \%$. No cyst was produced when vegetative cells were inoculated into fresh MW2 medium and normal vegetative growth occurred.

The effect of temperature on the encystment is shown in Fig. 11, as a function of incubation temperature, at $5,10,15$ and $20^{\circ} \mathrm{C}$. The optimum temperature for encystment was $15^{\circ} \mathrm{C}$, and the frequency was $40 \%$. The frequencies of encystment at 20 and $10^{\circ} \mathrm{C}$ were 25 and $20 \%$, respectively. No encystment was observed at $5^{\circ} \mathrm{C}$ within 30 days' incubation, and most cells remained as vegetative cells.

The dependence on light intensity of encystment was studied (Fig. 12). At 10,000 lx (14: 10 LD cycle) cysts were produced at the frequency of $40 \%$ for 30 days' incubation. The optimum light intensity for encystment was $10,000 \mathrm{~lx}$. The frequencies of encystment at 5,000,2,000, and $1,000 \mathrm{~lx}$ were 39,23 , and $5 \%$, respectively. The cyst was not produced in continuous darkness.

\section{Discussion}

We observed that the vegetative division of $P$. penardii was different from those of other Peridinium. In $P$. penardii the vegetative cells of exponential phase divided into two, four or rarely eight daughter cells in MW2 medium in contrast with the binary fission of other Peridinium. ${ }^{4,6)}$ This characteristic event in the cell division was also observed in situ (unpublished data) and so it has been usually found the various size cells in situ as well as in vitro. The division of $P$. penardii occurred inside the theca as in the case of $P$. cunningtonii, although the vegetative division of Peridinium sp. B3 occurred outside the theca through the peanuts shaped stage. ${ }^{\text {p) }}$

The optimum temperature for cell yields of $P$. penardii was $15^{\circ} \mathrm{C}$, while the optimum temperature of $\boldsymbol{P}$. cunningtonii was $20^{\circ} \mathrm{C}$.) It was reported that the cysts of $\boldsymbol{P}$. cunningtonii started to excyst at $\left.15^{\circ} \mathrm{C} .5\right)$ These data support the fact that the succession of dominant species from $P$. penardii to $P$. cunningtonii occurs when water temperature in Nagase Reservoir is above $17^{\circ} \mathrm{C}$ in late spring to early summer.

The life cycle of $P$. penardii is similar to that of $P$. cunningtoni ${ }^{4)}$ in the following ways: i) sexuality is induced in nitrogen and phosphorus deficient medium; ii) gametes are similar in shape to vegetative cells; iii) sexual reproduction is isogamous and homothallic; iv) gametes fuse during the dark phase of the LD cycle; v) planozygotes have two longitudinal flagella; and vi) mature cysts are released by splitting of the girdle region of the theca of the planozygote. The differences with $P$. cunningtonii include; i) vegetative cells of $P$. penardii divide into two, four or rarely eight daughter cells in contrast with the binary fission of $P$. cunningtonii; ii) planozygotes don't have red body in $P$. penardii as opposed to two red bodies in $P$. cunningtonii. Sexual reproduction of $P$. penardii is also similar to those of $P$. cinctum, ${ }^{7)}$ $P$. willei ${ }^{\text {g) }}$ P. gatunense, ${ }^{07}$ and Peridinium sp. B3, ${ }^{, 3}$ except for the amount of red bodies and gamete formation. Although all these Peridinium are homothallic, sexual reproduction of $P$. volzii is isogamous and heterothallic with two mating types. ${ }^{11}$ Sexual reproduction of Protogonyaulax catenella was heterothallic and fusion was started by the mixing of two mating types. ${ }^{12}$.

Cysts of $P$. penardii are produced in N-free, or $\mathrm{N}$ - and P-free medium under 10,000 lx illumination at $15^{\circ} \mathrm{C}$ at the maximum frequency of $40 \%$. In P-free medium and fresh medium cysts are produced at the frequency of 5 and $0 \%$, respectively. In comparison with that of $P$. cunningtonii, , these encystment frequencies of $P$. penardii are low, but the condition of regulating encystment was almost similar to. In other six species of freshwater Peridinium, ${ }^{\gamma-\theta, 11,13,14)}$ sexual encystment was observed in only $\mathrm{N}$-deficient medium, and was not effective in P-deficient medium. In other marine dinoflagellates Gonyaulax tamarensis $^{15)}$ and $G$. monilata, ${ }^{16)}$ the cysts were formed in nitrogen-deficient medium, and the cysts of the latter were observed also in late stationary cul- 
tures.

Frequency of cyst formation in $P$. penardii is maximal at light intensity of 5,000 to $10,000 \mathrm{~lx}$, and at temperature of $15^{\circ} \mathrm{C}$. The cyst is not produced in continuous darkness as well as in other dinoflagellates. $4,7-\theta, 11,13,18,18)$ These physical conditions for its encystment are similar to the condition for its growth. It was reported that gametes of Gymnodinium pseudopalustre, a freshwater dinoflagellate, were formed when a culture actively growing at $21^{\circ} \mathrm{C}(14 \mathrm{~h} \mathrm{light})$ was exposed to a short-day treatment $(10 \mathrm{~h}$ light $)$ at $15^{\circ} \mathrm{C}$ and gametes of Woloszynskia apiculata were formed when vegetative cells were inoculated in moderate $\mathbf{N}$ and $\mathbf{P}$ deficient medium and put into a lower light intensity (from 14,000 to $2,0001 x$ ). ${ }^{17}$ The environmental factors influencing encystment of $P$. penardii in addition to those of other dinoflagellates suggests that sexual reproduction in dinoflagellates is mainly induced by the nutrient stress following by the temperature and light.

Cysts of $P$. penardii were found in the sediment of Nagase Reservoir after its bloom in winter and early spring. ${ }^{3)}$ In the same reservoir the planozygotes in $P$. cunningtonii were found in the algal samples collected from the bloom. In the Lake Kinneret, it was also observed that the cysts of $\boldsymbol{P}$. cinctum were formed during the whole blooming period, while a massive encystment was never observed at the end of the bloom. ${ }^{18)}$ The cysts of $P$. penardii formed during bloom must sink to sediment in the reservoir and revive as a seed population.

\section{Acknowledgements}

The authors wish to thank Messrs. M. Uchida and H. Kido for their technical assistances, and Prof. H. Kadota, Kinki University, for critical advice. This work was supported in part by grants from the Nippon Life Insurance Fundation and from the Ministry of Education, Science and Culture, Japan (Nos. 59760137 and 60760144).

\section{References}

1) T. Itoh: Bull. Plankton. Soc. Japan, 26, 113-116 (1979).

2) Y. Hata: Res. Data Natl. Inst. Enviro. Stud., No. 24, 15-28 (1982).

3) H. Kadota, Y. Ishida, Y. Sako, and Y. Hata: Mem. Coll. Agric., Kyoto Univ., No. 123, 27-36 (1984).

4) Y. Sako, Y. Ishida, H. Kadota, and Y. Hata: Nippon Suisan Gakkaishi, 50, 743-750 (1984).

5) Y. Sako, Y. Ishida, H. Kadota, and Y. Hata: Nippon Suisan Gakkaishi, 51, 267-272 (1985).

6) Y. Sako, M. Nakanishi, T. Konda, Y. Ishida, H. Kadota, K. Shrestha, H. R. Bhandary, and R. L. Shrestha: Bull. Jpn. Soc. Microb. Ecol. (Nihon Biseibutsu Seitai Gakkaiho), 1, 19-27 (1986).

7) L. A. Pfiester: J. Phycol., 11, 259-265 (1975).

8) L. A. Pfiester: J. Phycol., 12, 234-248 (1976).

9) L. A. Pfiester: J. Phycol., 13, 92-95 (1977).

10) M. M. Watanabe: Res. Data Natl. Inst. Environ. Std. No. 24, 111-121 (1983).

11) L. A. Pfiester and J. J. Skvarla: Phycologia, 18, 13-18 (1979).

12) S. Yoshimatsu: Bull. Plankton. Soc. Japan, 28, 131-139 (1981).

13) L. A. Pfiester and J. J. Skvarla: Amer. J. Bot., 67, 955-958 (1980).

14) L. A. Pfiester, P. Timpano, J. J. Skvarla, and J. R. Holt: Amer. J. Bot., 71, 1121-1127 (1984).

15) D. H. Turpin, P.E.R. Dobell, and F.J.R. Taylor: J. Phycol., 14, 235-238 (1978).

16) L. M. Walker and K. A. Steidinger: J. Phycol., 15, 312-315 (1979).

17) H. A. von Stosch: Br. phycol. J., 8, 105-134 (1973).

18) U. Pollingher and C. Serruya: J. Phycol., 12, 162-170 (1976). 